\title{
Interaction of acetyl-CoA carboxylase enzyme inhibiting herbicides with auxin herbicides on ryegrass
}

\author{
Rubens Antonio Polito ${ }^{1}$ (D) Larissa Pasqualotto ${ }^{2}$ (D) Rafael Dysarz ${ }^{2}$ (D) Rafaela Cinelli ${ }^{2}$ (D) \\ Tamara Heck ${ }^{1}$ (D) Anderson Luis Nunes ${ }^{2 *}$ (D)
}

${ }^{1}$ Centro de Herbologia (CEHERB), Universidade Federal Pelotas (UFPel), Capão do Leão, RS, Brasil.

${ }^{2}$ Instituto Federal do Rio Grande do Sul (IFRS), Campus Sertão, 97170-000, Sertão, RS, Brasil. E-mail: anderson.nunes@sertao.ifrs.edu.br. "Corresponding author.

ABSTRACT: This study aimed to evaluate the antagonistic effect of the mixture ofacetyl coenzyme-A carboxylase (ACCase) enzyme inhibiting herbicides and auxin herbicides in Lolium multiflorum and to determine mechanisms to mitigate this possible effect. The first experiments were conducted by associating the herbicide clethodim (108 $\mathrm{g}$ a.i. $\left.\mathrm{ha}^{-1}\right)$, quizalofop-p-ethyl (54 $\mathrm{g}$ a.i. $\mathrm{ha}^{-1}$ ), and clethodim + quizalofopp-ethyl $\left(108+54 \mathrm{~g}\right.$ a.i. $\left.\mathrm{ha}^{-1}\right)$ with 2,4-D (1005 $\mathrm{g}$ a.e. $\left.\mathrm{ha}^{-1}\right)$ or triclopyr $\left(720 \mathrm{~g}\right.$ a.e. $\left.\mathrm{ha}^{-1}\right)$, in addition to the sole application of the respective graminicides. Another experiment included clethodim (54; 81; 108; 162; $216 \mathrm{~g}$ a.i. ha $\left.{ }^{-1}\right)$, quizalofop-p-ethyl $(27 ; 40.5 ; 54 ; 81 ; 108 \mathrm{~g}$ a.i. $\left.\mathrm{ha}^{-1}\right)$, and clethodim + quizalofop-p-ethyl $\left(54+27 ; 81+40.5 ; 108+54 ; 162+81 ; 216+108 \mathrm{~g}\right.$ a.i. ha $\left.\mathrm{a}^{-1}\right)$ mixed with 2,4-D $\left(1005 \mathrm{~g}\right.$ a.e. $\left.h \mathrm{a}^{-1}\right)$, or triclopyr (720 $\mathrm{g}$ a.e. $\left.\mathrm{ha}^{-1}\right)$, in addition to the control treatments without herbicide application. In the second experiment, herbicides clethodim $\left(108 \mathrm{~g}\right.$ a.i. $\left.\mathrm{ha}^{-1}\right)$, quizalofop-p-ethyl $\left(54 \mathrm{~g}\right.$ a.i. $\left.\mathrm{h}^{-1}\right)$, and clethodim + quizalofop-p-ethyl $\left(108+54 \mathrm{~g}\right.$ a.i. $\left.\mathrm{ha}^{-1}\right)$ in combination with the herbicides 2,4-D (1005 g a.e. $\left.\mathrm{ha}^{-1}\right)$ or triclopyr (720 $\mathrm{g}$ a.e. $\left.\mathrm{ha}^{-1}\right)$ had malathion $\left(1000 \mathrm{~g}\right.$ a.i. $\left.\mathrm{ha}^{-1}\right)$ or glyphosate $\left(720 \mathrm{~g}\right.$ a.e. $\left.\mathrm{ha}^{-1}\right)$ mixed, in addition to the sole applications of the graminicides. The herbicide clethodim + quizalofop-p-ethyl did not present an antagonistic interaction with the auxin herbicides, and obtained $85 \%$ weed control. To obtain control similar to the sole application of this graminicide, the dose of the herbicide clethodim needs to be increased by $20 \%$. However, the mixture of the herbicide quizalofop-p-ethyl with 2,4-D and triclopyr affects the ryegrass control. The use of strategies that increase the absorption of ACCase herbicides or the inhibition of P450 enzymes are ways to mitigate the antagonistic effect caused by the association of the two auxin herbicides.

Key words: Lolium multiflorum; clethodim; quizalofop-p-ethyl; synergism; antagonism.

Interação de herbicidas inibidores da enzima acetil-CoA carboxilase com herbicidas auxínicos sobre azevém

\begin{abstract}
RESUMO: $O$ objetivo do trabalho foi avaliar o efeito antagônico da mistura de herbicidas inibidores da enzima ACCase e herbicidas auxínicos em Lolium multiflorum e determinar mecanismos de mitigação deste possivel efeito. No primeiro momento foram conduzidos experimentos associando o herbicida clethodim (108 g i.a. $\left.\mathrm{ha}^{-1}\right)$, quizalofop-p-ethyl $\left(54 \mathrm{~g}\right.$ i.a. $\left.\mathrm{ha}^{-1}\right)$ e clethodim + quizalofop-p-ethyl $(108+54 \mathrm{~g}$ i.a. $\left.\mathrm{ha}^{-1}\right)$ com 2,4-D (1005 g e.a. $\left.\mathrm{ha}^{-1}\right)$ ou triclopyr (720 g e.a. ha $\left.\mathrm{a}^{-1}\right)$, além da aplicação isolada dos respectivos graminicidas. Outro experimento contou com clethodim (54; 81; 108; 162; 216 g i.a ha $\left.{ }^{-1}\right)$, quizalofop-p-ethyl $\left(27 ; 40,50 ; 54 ; 81 ; 108 \mathrm{~g}\right.$ i.a ha $\left.\mathrm{h}^{-1}\right)$ e clethodim + quizalofop-pethyl $\left(54+27 ; 81+40,50 ; 108+54 ; 162+81 ; 216+108 \mathrm{~g}\right.$ i.a ha $\left.a^{-1}\right)$ em mistura com 2,4-D (1005 g e.a ha $\left.{ }^{-1}\right)$ ou triclopyr $\left(720 \mathrm{~g}\right.$ e.a. ha $\left.a^{-1}\right)$, além das testemunhas sem aplicação herbicida. No segundo momento os herbicidas clethodim (108 g i.a. ha $\left.a^{-1}\right)$, quizalofop-p-ethyl (54 g i.a. $\left.\mathrm{ha}^{-1}\right)$ e clethodim + quizalofop-p-ethyl (108 $+54 \mathrm{~g}$ i.a. $\mathrm{ha^{-1 }}$ ) em associação com os herbicidas 2,4-D (1005 g e.a ha-l) ou triclopyr (720 g e.a. $\left.\mathrm{ha}^{-1}\right)$, contaram com adição de malathion (1000 $\mathrm{g}$ i.a. $\left.\mathrm{ha}^{-1}\right)$ ou glyphosate $\left(720 \mathrm{~g}\right.$ e.a. ha $\left.\mathrm{h}^{-1}\right)$, além das aplicações isoladas dos graminicidas. O herbicida clethodim + quizalofop-p-ethyl não apresentou interação antagônica com os herbicidas auxínicos, obtendo controle de $85 \%$. Já para o herbicida clethodim é necessário o aumento de dose em $20 \%$ é capaz de obter controle similar a aplicação isolada deste graminicida. Porém para o herbicida quizalofop-p-ethyl a mistura com os herbicidas 2,4-D e triclopyr repercute na diminuição do controle do azevém. $O$ uso de estratégias que aumente a absorção do herbicida inibidor de ACCase ou a inibição das enzimas P450 são formas de mitigar o efeito antagônico causado pela associação destes dois tipos de herbicidas.
\end{abstract}

Palavras-chave: Lolium multiflorum; clethodim; quizalofop-p-ethyl; sinergismo; antagonismo.

\section{INTRODUCTION}

Ryegrass (Lolium multiflorum) is an annual weed that has natural reseeding capacity, and it is present in wheat, maize, oats, and barley crops (KASPARY et al., 2014). The control of this weed was mainly conducted with the use of glyphosate herbicide that inhibits the EPSPS enzyme. However, 
in 2003, the first case of L. multiflorum resistance to this herbicide was recorded in orchards and soybean fields in the state of Rio Grande do Sul (HEAP, 2020). Thus, the use of herbicides inhibiting the enzyme acetyl coenzyme-A carboxylase (ACCase) has become the best option.

ACCase enzyme inhibiting herbicides show selectivity in Magnoliopsida plants (VIDAL \& MEROTTO JR., 2001). Three chemical groups belong to this mechanism of action: aryloxyphenoxypropionate (FOP), cyclohexanedione (DIM), and phenylpyrazoline (DEN) (AHMADHAMDANI et al., 2012; IWAKAMI et al., 2018). The death of the plant occurs because these herbicides inhibit the action of the ACCase, which participates in the biosynthesis of fatty acids, thus blocking the production of phospholipids that act on plant growth constituting the formation of membranes (DE OLIVEIRA Jr., 2011).

The tank mixture between ACCase enzyme inhibiting herbicides and auxin herbicides impair the performance of the former (ABIT et al., 2011; COX \& ASKEW, 2014; WEBSTER et al., 2019). However, the existence and intensity of the antagonistic effect depend on the target species. Auxin herbicides are selective to Poaceae and their presence stimulates the expression of P450 monooxygenase genes that can metabolize herbicides (YU \& POWLES, 2014). The hypotheses of this study are as follows: a) the mixture of ACCase enzyme inhibiting herbicides and auxin herbicides causes an antagonistic effect over ryegrass control; b) increasing the dose of the ACCase enzyme inhibiting herbicide may mitigate the antagonistic effect caused by the addition of the auxin herbicide; c) the mechanism of antagonism is caused by the expression of P450 monooxygenase enzymes stimulated by the auxin herbicide; and d) the antagonistic effect may be mitigated by increasing the absorption of the ACCase herbicide orby inhibiting the P450 enzymes. Thus, this study aimed to evaluate the antagonistic effect of the mixture of ACCase inhibiting herbicides and auxin herbicides in L. multiflorum, determining mechanisms to mitigate this effect.

\section{MATERIALS AND METHODS}

The experiments were conducted in the municipality of Sertão, Rio Grande do Sul in 2018, under field conditions. The climate of the region is characterized as $\mathrm{Cfa}$, according to the Köppen classification, while the soil is classified as typical dystroferric Red Nitosol (STRECK et al., 2018). The application of the herbicides in the experiments was performed with a backpack sprayer pressurized with $\mathrm{CO}_{2}$, equipped with nozzles of the 110.02 air fan type, calibrated to a spray volume of $150 \mathrm{~L} \mathrm{ha}^{-1}$. The experimental design used was randomized blocks (RBD) with four replications.

Evaluation of the mixture and dose-response curves of ACCase enzyme inhibiting herbicides associated with 2,4-D or triclopyr

The experiments included the sole application of the herbicides clethodim (108 $\mathrm{g}$ a.i. ha $\left.{ }^{-1}\right)$, quizalofop-p-ethyl (54 g a.i. $\left.\mathrm{ha}^{-1}\right)$, and clethodim + quizalofop-p-ethyl $\left(108+54 \mathrm{~g}\right.$ a.i. ha $\left.{ }^{-1}\right)$, which were the recommended doses for ryegrass control, and these were associated with the herbicides 2,4-D (1005 g a.e. ha $\left.{ }^{-1}\right)$ or triclopyr (720 g a.e. ha $\left.{ }^{-1}\right)$. Three experiments were conducted, totaling six doseresponse curves with the herbicides clethodim (54; $81 ; 108 ; 162 ; 216 \mathrm{~g}$ a.i. ha $\left.{ }^{-1}\right)$, quizalofop-p-ethyl $\left(27 ; 40.5 ; 54 ; 81 ; 108 \mathrm{~g}\right.$ a.i. $\left.\mathrm{ha}^{-1}\right)$ and clethodim + quizalofop-p-ethyl $(54+27 ; 81+40.5 ; 108+54$; $162+81 ; 216+108 \mathrm{~g}$ a.i. $\left.\mathrm{ha}^{-1}\right)$. All doses in all curves were associated with 2,4-D (1005 g a.e. ha ${ }^{-1}$ ) or triclopyr ( 720 g a.e. ha $\left.^{-1}\right)$.

The ryegrass density in the experimental area was 64 plants $\mathrm{m}^{-2}$. The weather conditions during the trials are shown in figure 1. At the time of application on July 5, 2018, plants were at the beginning of flowering.

\section{Determination of the mechanism of antagonism}

The hypothesis is that auxin herbicides stimulate the expression of genes encoding cytochrome P450 monooxygenase enzymes that are responsible for the metabolism of the ACCase enzyme inhibiting herbicides. In this experiment to mitigate the antagonistic effect, the insecticide malathion, which is known to inhibit enzymes of the complex P450 monooxygenase, was used. Treatments are described in table 1 . The density of ryegrass was 37 plants $\mathrm{m}^{-2}$,and the plants were between stages of flowering and grain filling at the time of application. The application took place on September 11, 2018. Weather conditions during the trial are shown in figure 1.

\section{Data assessments and analytics}

The ryegrass control evaluations were performed at 14, 21, 28, and 35 days after application (DAA), where $0 \%$ represents no herbicide effect and $100 \%$ corresponds to the death of the plants. In the experiment to determine the mechanism of antagonism, regrowth evaluation was also performed 


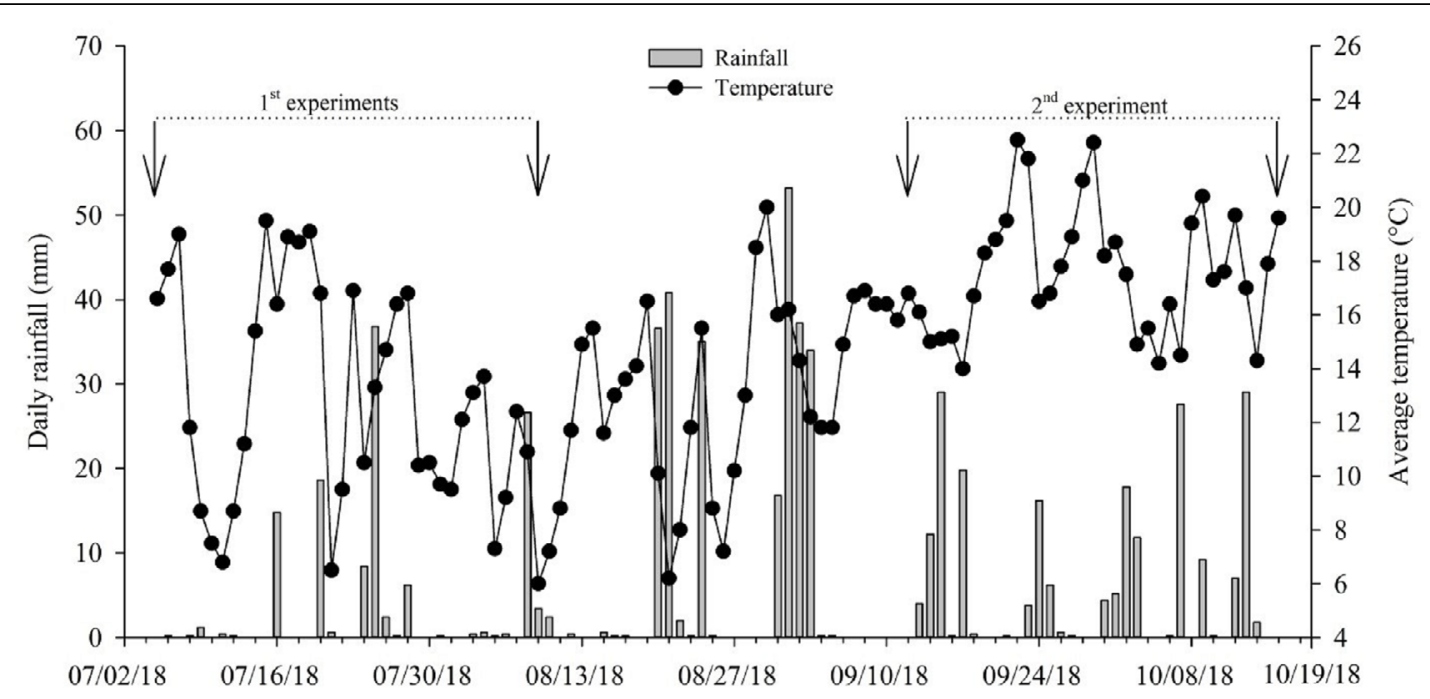

Figure 1 - Climatic conditions from 07/05/2018 to 10/16/2018. The first experiments correspond to the period of the doseresponse curve experiments of graminicides associated with 2,4-D or triclopyr and the sole application of clethodim $\left(108 \mathrm{~g}\right.$ a.i. $\left.\mathrm{ha}^{-1}\right)$, quizalofop-p-ethyl $\left(54 \mathrm{~g}\right.$ a.i. ha $\left.\mathrm{h}^{-1}\right)$, and clethodim + quizalofop-p-ethyl $\left(108+54 \mathrm{~g} \mathrm{a.i.} \mathrm{ha}{ }^{-1}\right)$. The second experiment refers to the experiment period for determining the antagonism mechanism.

Source: IFRS meteorological station - Campus Sertão.

with the aid of a square frame placed in the center of the plot and measuring $0.5 \times 0.5 \mathrm{~m}^{2}$. The dry matter of the plants (DM) was collected at $35 \mathrm{DAA}$ and the material was packed in paper bags and heated in an oven at $\pm 65^{\circ} \mathrm{C}$ until it reached a constant weight. The mathematical model proposed by COLBY (1967) was followed to determine the antagonistic effect. The data were also submitted to the analysis of variance using the F-test and the means were compared using the ASSISTAT software, version 7.7. The dose ratio of graminicides associated with 2,4-D and triclopyr in the control of L. multiflorum and DM was adjusted through asigmoidal regression of three parameters:

$$
Y=\frac{a}{\left(1+\exp \left(-\frac{(x-x 0)}{b}\right)\right)}
$$

where $\mathrm{y}=$ ryegrass control/DM; $\mathrm{a}=$ difference between the maximum and the minimum points; $\mathrm{x}=$ dose of the graminicide; $\mathrm{x}_{0}=$ dose for $50 \%$ control;

Table 1 - Treatments to mitigate the antagonistic effect of auxin herbicides associated with graminicides.

\begin{tabular}{lc}
\hline Treatments & Dosages g a.i. ha ${ }^{-1}$ or g a.e. ha $^{-1}$ \\
\hline Control & - \\
Glyphosate1 & 720 \\
\hline ACCase234 & ACCase234 \\
Glyphosate + ACCase234 & $720+$ ACCase 234 \\
Glyphosate + 2,4-D + ACCase234 & $720+1005+$ ACCase234 \\
Malathion + 2,4-D + ACCase234 & $1000+1005+$ ACCase234 \\
\hline Glyphosate + triclopyr + ACCase234 & $720+720+$ ACCase234 \\
\hline Malathion + triclopyr + ACCase234 & $1000+720+$ ACCase234 \\
\hline
\end{tabular}

${ }^{1}$ glyphosate ammonium salt; ${ }^{2}$ clethodim (108 g a.i. $\left.\mathrm{L}^{-1}\right) ;{ }^{3}$ quizalofop-p-ethyl $\left(54 \mathrm{~g}\right.$ a.i. $\left.\mathrm{L}^{-1}\right) ;{ }^{4}$ clethodim + quizalofop-p-ethyl (108+54 g a.i. $\left.\mathrm{L}^{-1}\right)$. Addition of alkyl ester ethoxylated adjuvant to phosphoric acid $0.5 \% \mathrm{v} / \mathrm{v}$. 
and $\mathrm{b}=$ slopeof the curve. The calculations were made using the SIGMAPLOT software, version 12.5.

\section{RESULTS AND DISCUSSION}

\section{Is there an antagonistic effect?}

Considering that 2,4-D and triclopyr herbicides do not have control over ryegrass, since plants of this family have a tolerance to them, the expected control of the mixture is the same as the observed control of the graminicide in a sole application (GUERRA et al., 2013). The COLBY's mathematical model does not conside the statistical comparison, but considers an antagonistic effect when the observed value (control) is lower than expected; thus, the values were compared using the $t$-test (MATZENBACHER et al., 2015; TREZZI et al., 2016; DIESEL et al., 2018).

The association of synthetic auxins with clethodim resulted in a reduction of ryegrass control (Figures 2B and 2C), with no difference between the auxins. Concerning quizalofop-p-ethyl, the antagonism was only evident in the evaluations conducted at 28 and 35 DAA (Figures $2 \mathrm{~B}$ and 2C). Herbicides clethodim and quizalofop-p-ethyl when mixed with dicamba had reduced control over volunteer corn (UNDERWOOD et al., 2016). For the herbicide quizalofop-p-ethyl, the antagonistic effect of

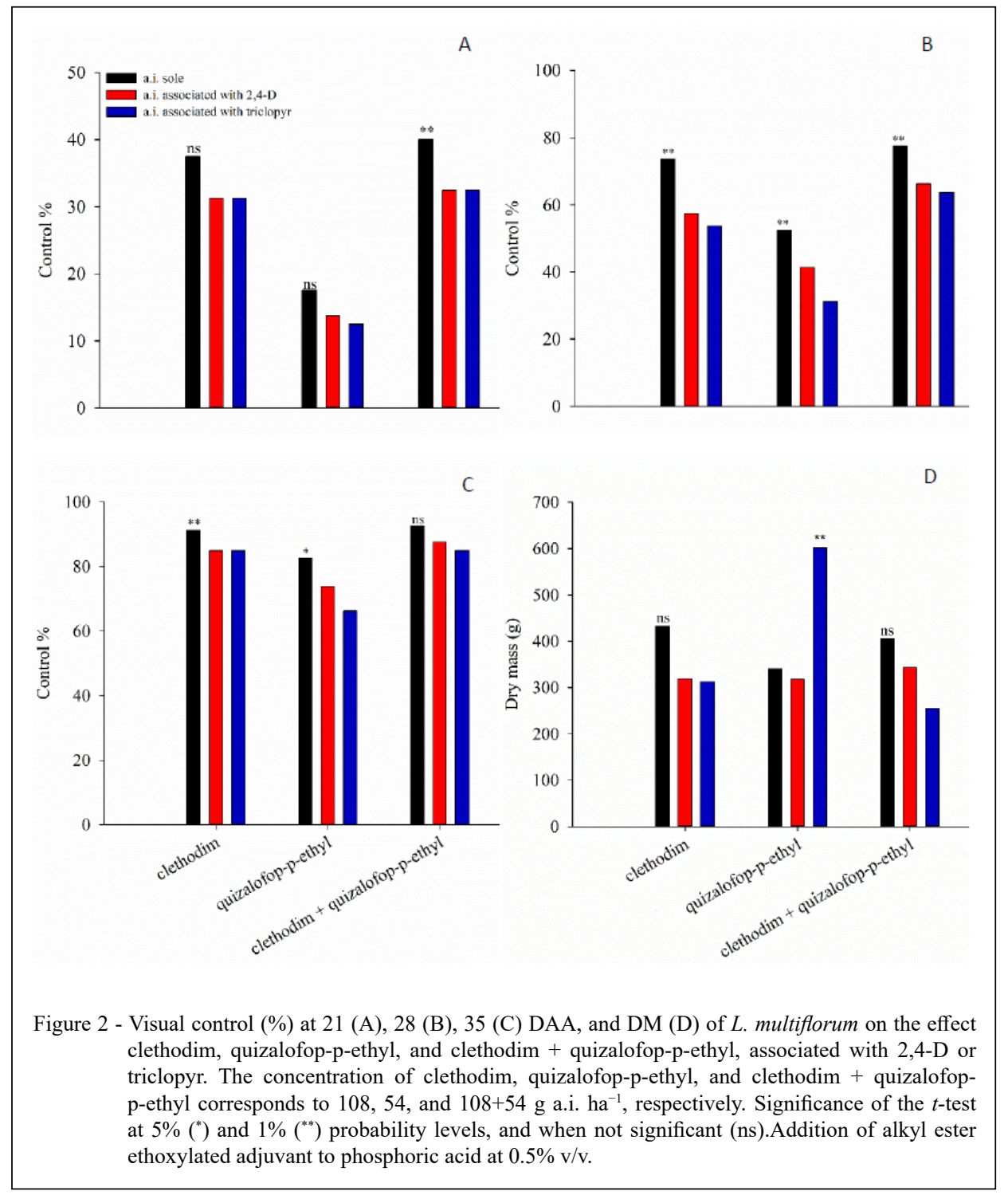

Ciência Rural, v.51, n.4, 2021. 
triclopyr was higher than that of 2,4-D (Figures 2C and 2D). With respect to the formulated mixture of clethodim + quizalofop-p-ethyl, the auxin herbicides had a negative effect only at 21 and 28 DAA (Figures 2A and 2B), with no differences between the auxins corresponding to the level of antagonism. Regarding DM, the combination of quizalofop-p-ethyl with triclopyr resulted in high accumulation when compared to the sole application of quizalofop-pethyl (Figure 2D).

The mixture of synthetic auxins with the ACCase enzyme inhibiting herbicides caused an antagonistic effect over ryegrass control, considering COLBY's mathematical model (1967). For clethodim and clethodim + quizalofop-p-ethyl, the level of antagonism between 2,4-D and triclopyr was the same. However, for quizalofop-p-ethyl, the antagonistic effect of triclopyr was higher than that of 2,4-D. Triclopyr applied five days earlier or mixed with cyhalofop reduced control by more than $25 \%$ over two populations of ricegrass (SCHERDER et al., 2005).

\section{Is it possible to compensate for the antagonistic effect by increasing the dose of the graminicide?}

The herbicide quizalofop-p-ethyl presented the lowest controls of ryegrass in the booting stage (Figures 3B and 3E). Moreover, an antagonistic effect was present with the recommended doses (Figures $3 \mathrm{~A}-3 \mathrm{~F}$ ), and for quizalofop-p-ethyl, the antagonism level of triclopyr was higher than that of 2,4-D (Figures 3B and 3E). However, in some studies, the association of this auxin herbicide to quizalofop did not lead to a loss of efficiency (LEWIS et al., 2010; DOROH et al., 2011; LANCASTER et al., 2019).

The sole dose of clethodim (108 g a.i. $\mathrm{ha}^{-1}$ ) obtained $21 \%$ and $91 \%$ control at 14 and 35 DAA, respectively (Figures 3A and 3D). Not even the doubling of the clethodim dose could compensate for the antagonistic effect of the synthetic auxins at 14 DAA (Figure 3A). At 35 DAA, an increase of approximately $20 \%$ of the clethodim dose was sufficient to compensate for the antagonistic effect, when considering the standard deviation generated by the curve (Figure 3D). The sole dose of quizalofopp-ethyl (54 g a.i. ha ${ }^{-1}$ ) obtained $9 \%$ and $82 \%$ control over ryegrass at 14 and 35 DAA, respectively (Figures 3B and 3E). The antagonistic effect on quizalofop-p-ethyl was only observed in the evaluation performed at 35 DAA, where not even twice the recommended dose could compensate the antagonistic effect of 2,4-D and triclopyr (Figure 3E). The dose of the formulated mixture of clethodim + quizalofop-p-ethyl $\left(108+54 \mathrm{~g}\right.$ a.i. $\left.\mathrm{ha}^{-1}\right)$ without the presence of synthetic auxins obtained $19 \%$ and $92 \%$ ryegrass control at 14 and $35 \mathrm{DAA}$, respectively (Figures 3C and 3F). No antagonistic effect was observed on clethodim + quizalofop-p-ethyl in any of the evaluations (Figures $3 \mathrm{C}$ and $3 \mathrm{~F}$ ), considering the standard deviation of the curve.

The parameters of the mathematical model generated from visual control data at 35 DAA showed that the dose needed to control $50 \%$ of the population $\left(\mathrm{C}_{50}\right)$ when sprayed with clethodim associated with 2,4-D or triclopyr was 43.68 or $44.64 \mathrm{~g} \mathrm{ha}^{-1}$, respectively (Table 2). As for quizalofop-p-ethyl, doses of 33.97 and $41.58 \mathrm{~g} \mathrm{ha}^{-1}$ are needed, when mixed with 2,4-D and triclopyr, respectively. The $\mathrm{C}_{50}$ values of the formulated mixture of ACCases were the lowest, requiring $35.76+7.45 \mathrm{~g} \mathrm{ha}^{-1}$ when mixed with $2,4-\mathrm{D}$ and $37.20+7.75 \mathrm{~g} \mathrm{ha}^{-1}$ when mixed with triclopyr.

Considering that the minimum acceptable control of an herbicide is $80 \%$, the values of $\mathrm{C}_{80}$ were generated to compare with the recommended dose of each herbicide. For clethodim associated with 2,4-D or triclopyr, the dose required to control $80 \%$ of the population was 79.20 or $86.16 \mathrm{~g} \mathrm{ha}^{-1}$, respectively (Table 2). Due to the low efficiency of quizalofopp-ethyl when in combination with synthetic auxins, the calculation of $\mathrm{C}_{80}$ values was not possible using the mathematical model. For clethodim + quizalofopp-ethyl mixed with 2,4-D or triclopyr, the dose required to control $80 \%$ of the population was 53.04 +11.05 or $58.56+12.20 \mathrm{~g} \mathrm{ha}^{-1}$, respectively (Table 2). Considering the standard deviation generated by the mathematical model for the values of $\mathrm{C}_{50}$ and $\mathrm{C}_{80}$, only a difference in the level of antagonism between 2,4-D and triclopyr existed for the herbicide quizalofop-p-ethyl, where the antagonism caused by triclopyr was more intense than that by $2,4-\mathrm{D}$ (Table 2).

In associations of clodinafop-propargyl with the herbicide $2,4-\mathrm{D}$, to achieve a result similar to $50 \%$ of the application of the sole graminicide over the same weed, an increase of $151 \%$ of the dose was required to compensate the association (TREZZI et al., 2007). In a previous study, differences between mimic herbicides were noted in association with haloxifop in the control of sourgrass, where dicamba and 2,4-D significantly decreased, in contrast to halauxifen-methyl (PEREIRA et al., 2018).

As the graminicide dose increased, lower DM accumulated, especially with the herbicides clethodim and clethodim + quizalofop-p-ethyl (Figures 4A and 4C). For these two, the recommended dose in association with the auxinic ones presented lower DM values compared to the recommended sole 


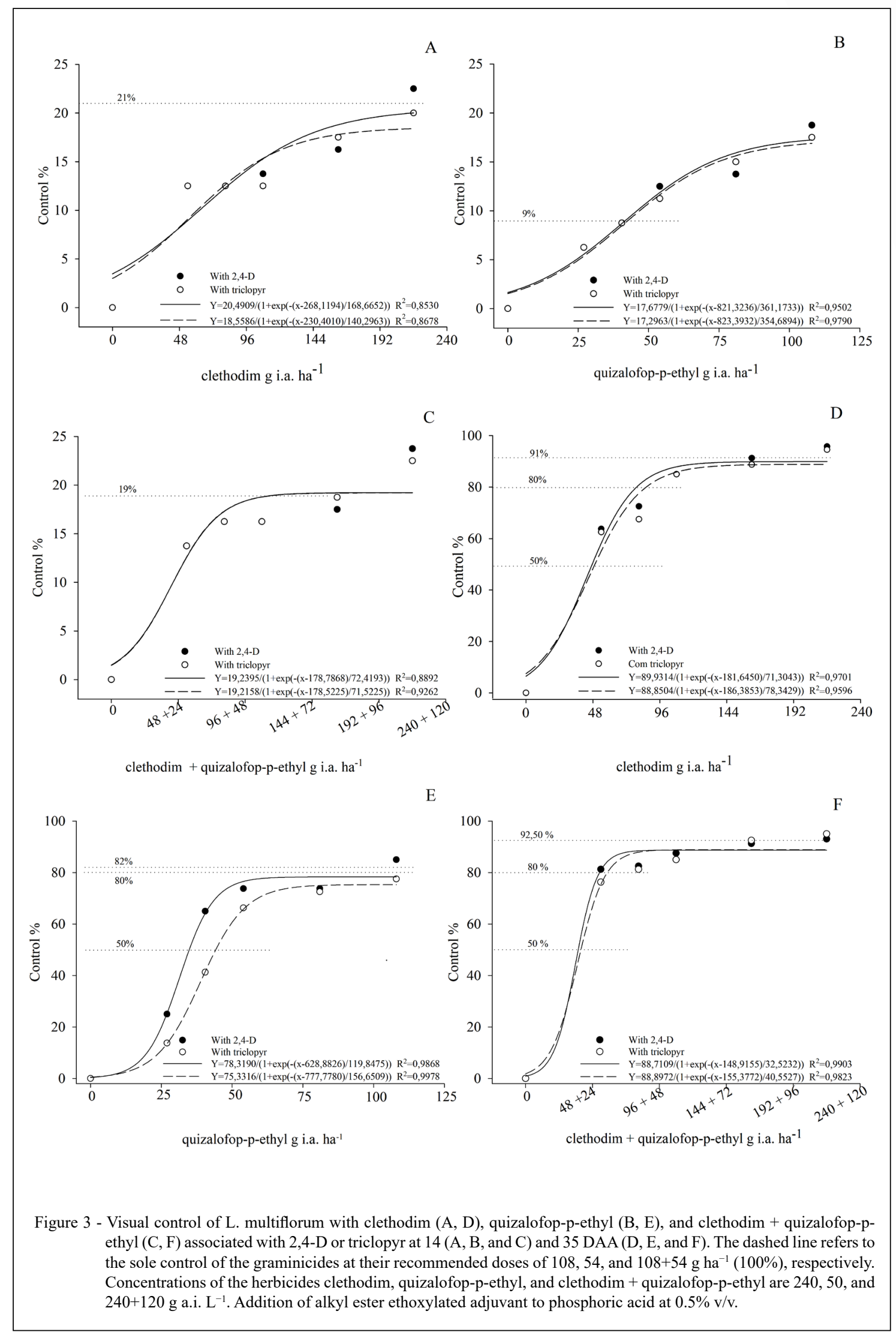

Ciência Rural, v.51, n.4, 2021. 
Table 2 - Parameters of the equations of the control variable (35 DAA) referring to the dose-response curves with the herbicides clethodim, quizalofop-p-ethyl, and clethodim + quizalofop-p-ethyl in association with 2,4-D or triclopyr in ml.

\begin{tabular}{lccccccc}
\hline ACCase Herbicide & Auxin mimic & $\mathrm{a}$ & $\mathrm{b}$ & $\mathrm{C} 50$ & $\mathrm{C} 80$ & $\mathrm{R}^{2}$ & $\mathrm{P}$ \\
\hline \multirow{2}{*}{ Clethodim } & $2,4-\mathrm{D}$ & 89.9 & 71.3 & $182(211-152)$ & 330 & 0.9701 & 0.0052 \\
& Triclopyr & 88.8 & 78.3 & $186(221-151)$ & 359 & 0.9596 & 0.0081 \\
\hline \multirow{2}{*}{ Quizalofop-p-ethyl } & $2,4-\mathrm{D}$ & 78.3 & 119.8 & $629(661-597)$ & $>2160$ & 0.9868 & 0.0015 \\
& Triclopyr & 75.3 & 156.6 & $778(793-762)$ & $>2160$ & 0.9978 & 0.0001 \\
Clethodim + & $2,4-\mathrm{D}$ & 88.7 & 32.5 & $149(206-91)$ & 221 & 0.9903 & 0.0010 \\
Quizalofop-p-ethyl & Triclopyr & 88.9 & 40.5 & $155(199-112)$ & 244 & 0.9823 & 0.0024 \\
\hline
\end{tabular}

(a) corresponds to the difference between the maximum and minimum points of the curve; (b) slope of the curve; $\left(\mathrm{C}_{50}\right)$ dose of herbicide capable of controlling $50 \%$ of the population; $\left(\mathrm{C}_{80}\right)$ dose of herbicide capable of controlling $80 \%$ of the population; $\left(\mathrm{R}^{2}\right)$ coefficient of determination; (P) significance; values in parenthesis are the error range. The concentrations of the herbicides clethodim, quizalofop-pethyl, and clethodim + quizalofop-p-ethyl are 240,50 , and $240+120 \mathrm{~g}$ a.i. $\mathrm{L}^{-1}$, respectively.

dose (not combined with auxin herbicides), showing synergism and no longer showing antagonism. In this sense, a contradiction is present between visual assessments and DM evaluations.

Visual control evaluations are subjective, and they consider the symptoms caused by the herbicides and the survival level of the plant, with regards to the control treatment. DM assessment is quantitative and considers the mass acquired during plant development. The effect of auxin herbicides may be similar to endogenous plant auxins and affects the growth (GAZOLA et al., 2019), but it allows ryegrass to survive the application of ACCase inhibiting herbicides. This fact was also observed in the previous experiment; although, antagonism or synergism was not significant for clethodim and clethodim + quizalofop-p-ethyl (Figure 2B). Biotypes of ryegrass resistant to diclofop-methyl, due to the metabolism of P450 enzymes, have slower growth and lower carbon fixation and liquid photosynthesis rates, compared to the sensitive biotype (VILAAIUB et al., 2005). Thus, the DM variable does not seem to be an adequate evaluation for studies of mixtures of synthetic auxin herbicides and ACCase inhibiting herbicides to control ryegrass in the early flowering phase.

Regarding the herbicide clethodim, a 20\% dose increase compensated for the antagonistic effect caused by the auxin herbicides. Determining the dose needed to compensate for the antagonistic effect on the herbicide quizalofop-p-ethyl was not possible as the effect was not overcome even the recommended dose was doubled. However, for the formulated mixture of clethodim + quizalofop-p-ethyl, no antagonistic effect was present.
What is the mechanism that generates antagonism and how to mitigate it?

The herbicide 2,4-D can induce the expression of genes encoding enzymes of the type P450 (HIROSE et al., 2007), as observed for Lolium rigidum (HAN et al., 2013). In some Poaceae species, the tolerance to ACCase herbicides is provided by the action of enzymes of the P450 monooxygenase complex. The selectivity of clodinafop in wheat, barley, and maize (KREUZ et al., 1991) and phenoxaprop-p-ethyl in barley (ROMANO et al., 1993) occurs due to the action of enzymes of the P450 type. Furthermore, ryegrass biotypes resistant to diclofop-methyl occur in South Australia due to metabolism by P450 type enzymes (VILA-AIUB et al., 2005). However, for herbicides belonging to the cyclohexanedione group, resistance reports are more linked to mutations at the site of action (WHITE et al., 2005). The detection of the occurrence of herbicide detoxification by P450 enzymes can be performed through the use of enzyme inhibitors (YASOUR et al., 2009), such as the organophosphate insecticide malathion (SIMINSZKY, 2006). Hence, a possible way to verify the mechanism of incompatibility orto mitigate the antagonistic effect of synthetic auxins would be the combination of malathion to inhibit P450 type enzymes generated from the application of auxin herbicides.

Moreover, another way of mitigating the antagonistic effect would be the combination of glyphosate herbicide in the mixture of ACCase + synthetic auxin. In glyphosate-resistant Poaceae biotypes, its sole application has a low control effect. If glyphosate herbicide is associated with ACCase enzyme inhibiting herbicide, the level of control 


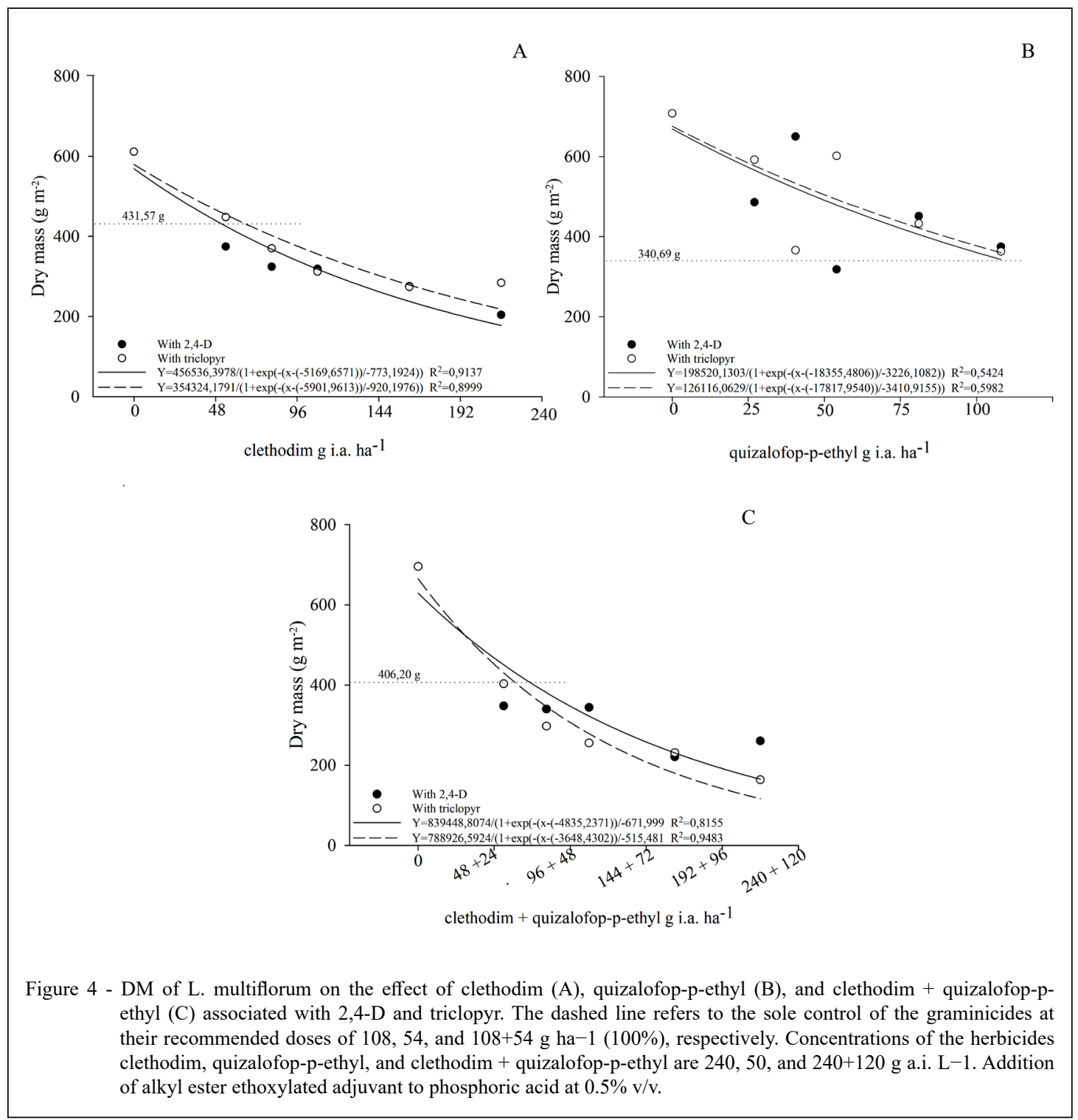

shows synergism, which is probably due to greater absorption and translocation of the ACCase inhibiting herbicide (BARROSO et al., 2014). With a larger number of molecules reaching the site of action, the efficiency of P450 type enzymes would be reduced.

For the herbicide clethodim mixed with 2,4-D or triclopyr, the addition of either glyphosate or malathion showed levels of control similar to the sole application of clethodim (Table 3). For 2,4-D, malathion presented greater ability to mitigate antagonistic effects, compared to glyphosate. In contrast, for triclopyr, glyphosate had a higher capacity to mitigate antagonistic effects, compared to malathion (Table 3 ). Therefore, reducing the antagonistic effect of 2,4-D and triclopyr in the control of ryegrass with clethodim associating malathion or glyphosate was possible.

For the herbicide quizalofop-p-ethyl mixed with 2,4-D, both glyphosate and malathion did not present levels of control similar to the sole application of quizalofop-p-ethyl in the final control evaluations (Table 3). As for triclopyr, glyphosate alone showed the ability to reduce antagonistic effects (Table 3 ). Thus, mitigation of the antagonistic effect of 2,4-D on quizalofop-p-ethyl was not possible, and mitigation of the antagonistic effect of triclopyr was only possible through the combination of glyphosate (Table 3 ).

For the formulated mixture of clethodim + quizalofop-p-ethyl associated with 2,4-D or triclopyr, 
Table 3 - Percentage of control and dry matter of L. multiflorum by clethodim, quizalofop-p-ethyl, and clethodim + quizalofop-p-ethyl associated with 2,4-D or triclopyr and/or glyphosate or malathion.

\begin{tabular}{|c|c|c|c|c|c|c|c|c|c|c|c|c|}
\hline \multirow[t]{2}{*}{ Treatment } & \multirow[t]{2}{*}{$\begin{array}{c}\text { Association } \\
\text { with } 2,4-\mathrm{D} \text { or } \\
\text { triclopyr }\end{array}$} & $---\cdot$ & & -- & $\% \mathrm{Co}$ & $\mathrm{rol}^{12}$ & & & ----- & \multicolumn{2}{|c|}{$\begin{array}{l}\text { Dry matter } \\
\quad\left(\mathrm{g} \mathrm{m}^{-2}\right)\end{array}$} & \multirow[t]{2}{*}{ Regrowth } \\
\hline & & \multicolumn{2}{|c|}{14 DAA } & \multicolumn{2}{|c|}{$21 \mathrm{DAA}$} & \multicolumn{2}{|c|}{$28 \mathrm{DAA}$} & \multicolumn{2}{|c|}{35 DAA } & & & \\
\hline \multicolumn{13}{|c|}{ 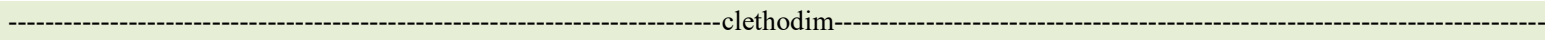 } \\
\hline Control & - & 0 & $\mathrm{c}$ & 0 & $\mathrm{~d}$ & 0 & $\mathrm{e}$ & 0 & e & 517.3 & $\mathrm{a}$ & - Yes \\
\hline glyphosate & - & 22 & $\mathrm{~b}$ & 37 & $\mathrm{c}$ & 47 & $\mathrm{~d}$ & 51 & $\mathrm{~d}$ & 263.7 & $\mathrm{bc}$ & - Yes \\
\hline Clethodim & - & 19 & $\mathrm{~b}$ & 42 & $\mathrm{bc}$ & 77 & $\mathrm{bc}$ & 91 & $a b$ & 244.0 & $\mathrm{bc}$ & No \\
\hline glyphosate + clethodim & - & 32 & $\mathrm{a}$ & 62 & $\mathrm{a}$ & 89 & $\mathrm{a}$ & 92 & $\mathrm{a}$ & 161.9 & $\mathrm{bc}$ & No \\
\hline glyphosate + clethodim & 2,4-D & 22 & $\mathrm{~b}$ & 37 & $\mathrm{c}$ & 72 & $\mathrm{c}$ & 82 & $\mathrm{c}$ & 284.3 & $\mathrm{bc}$ & - Yes \\
\hline malathion + clethodim & 2,4-D & 17 & $\mathrm{~b}$ & 47 & $\mathrm{~b}$ & 72 & $\mathrm{c}$ & 86 & $a b c$ & 301.4 & $\mathrm{bc}$ & - Yes \\
\hline glyphosate + clethodim & Triclopyr & 24 & $\mathrm{~b}$ & 57 & $\mathrm{a}$ & 82 & $\mathrm{ab}$ & 87 & $a b c$ & 135.5 & $\mathrm{c}$ & - Yes \\
\hline malathion + clethodim & Triclopyr & 17 & $\mathrm{~b}$ & 47 & $\mathrm{~b}$ & 75 & $\mathrm{c}$ & 85 & $\mathrm{bc}$ & 322.2 & $\mathrm{~b}$ & - Yes \\
\hline \multicolumn{2}{|c|}{-----------------------CV\%-------------------- } & \multicolumn{2}{|c|}{-----16.7----- } & \multicolumn{2}{|c|}{-----8.9------ } & \multicolumn{2}{|c|}{-----4.7----- } & \multicolumn{2}{|c|}{-----4.0------ } & \multicolumn{2}{|c|}{------26.9------ } & \\
\hline \multicolumn{13}{|c|}{ 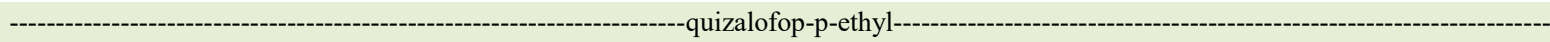 } \\
\hline Control & - & 0 & $\mathrm{~d}$ & 0 & $\mathrm{~d}$ & 0 & $\mathrm{~d}$ & 0 & e & 517.3 & a & - Yes \\
\hline glyphosate & - & 22 & a & 37 & $a b c$ & 47 & $\mathrm{c}$ & 51 & $\mathrm{~d}$ & 263.7 & $\mathrm{ab}$ & - Yes \\
\hline quizalofop-p-ethyl & - & 9 & $\mathrm{bc}$ & 41 & $\mathrm{ab}$ & 57 & $a b$ & 69 & $a b$ & 296.4 & $a b$ & - Yes \\
\hline $\begin{array}{l}\text { glyphosate }+ \\
\text { quizalofop-p-ethyl }\end{array}$ & - & 24 & $\mathrm{a}$ & 44 & $\mathrm{a}$ & 61 & $\mathrm{a}$ & 71 & a & 237.0 & $\mathrm{~b}$ & - Yes \\
\hline $\begin{array}{l}\text { glyphosate }+ \\
\text { quizalofop-p-ethyl }\end{array}$ & $2,4-\mathrm{D}$ & 12 & $\mathrm{~b}$ & 35 & $\mathrm{bc}$ & 49 & $\mathrm{c}$ & 60 & $\mathrm{c}$ & 317.0 & $a b$ & - Yes \\
\hline $\begin{array}{l}\text { malathion }+ \\
\text { quizalofop-p-ethyl }\end{array}$ & $2,4-\mathrm{D}$ & 5 & $\mathrm{~cd}$ & 31 & $\mathrm{c}$ & 47 & $\mathrm{c}$ & 57 & $\mathrm{~cd}$ & 248.0 & $\mathrm{~b}$ & - Yes \\
\hline $\begin{array}{l}\text { glyphosate }+ \\
\text { quizalofop-p-ethyl }\end{array}$ & Triclopyr & 29 & $\mathrm{a}$ & 48 & $\mathrm{a}$ & 51 & $\mathrm{bc}$ & 62 & $\mathrm{bc}$ & 265.0 & $a b$ & - Yes \\
\hline $\begin{array}{l}\text { malathion }+ \\
\text { quizalofop-p-ethyl }\end{array}$ & Triclopyr & 5 & $\mathrm{~cd}$ & 30 & $\mathrm{c}$ & 51 & $\mathrm{bc}$ & 59 & $\mathrm{~cd}$ & 279.4 & $a b$ & - Yes \\
\hline \multicolumn{2}{|c|}{---------------------CV\%"-------------------- } & \multicolumn{2}{|c|}{-----20.8----- } & \multicolumn{2}{|c|}{-----10.3---- } & \multicolumn{2}{|c|}{-----7.5----- } & \multicolumn{2}{|c|}{-----6.8------ } & \multicolumn{2}{|c|}{------37.0------ } & \\
\hline \multicolumn{13}{|c|}{ 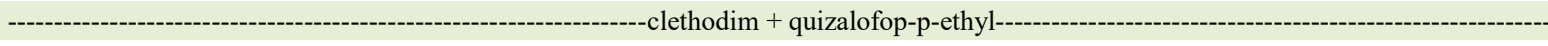 } \\
\hline Control & - & 0 & $\mathrm{f}$ & 0 & $\mathrm{~d}$ & 0 & $\mathrm{~d}$ & 0 & $\mathrm{~d}$ & 517.3 & $\mathrm{a}$ & - Yes \\
\hline glyphosate & - & 22 & $\mathrm{bc}$ & 37 & $\mathrm{bc}$ & 47 & $\mathrm{c}$ & 51 & $\mathrm{c}$ & 263.7 & $a b$ & - Yes \\
\hline $\begin{array}{l}\text { clethodim }+ \\
\text { quizalofop-p-ethyl }\end{array}$ & - & 18 & $\mathrm{~cd}$ & 40 & $\mathrm{bc}$ & 76 & $a b$ & 86 & $a b$ & 366.5 & $a b$ & - Yes \\
\hline $\begin{array}{l}\text { glyphosate + clethodim } \\
+ \text { quizalofop-p-ethyl }\end{array}$ & - & 33 & $\mathrm{a}$ & 60 & $\mathrm{a}$ & 82 & $\mathrm{a}$ & 91 & $\mathrm{a}$ & 208.1 & $\mathrm{~b}$ & - Yes \\
\hline $\begin{array}{l}\text { glyphosate + clethodim } \\
+ \text { quizalofop-p-ethyl }\end{array}$ & $2,4-\mathrm{D}$ & 26 & $\mathrm{~b}$ & 56 & $\mathrm{a}$ & 74 & $\mathrm{~b}$ & 82 & $\mathrm{~b}$ & 222.0 & $\mathrm{~b}$ & - Yes \\
\hline $\begin{array}{l}\text { malathion + clethodim } \\
+ \text { quizalofop-p-ethyl }\end{array}$ & $2,4-\mathrm{D}$ & 11 & e & 34 & $\mathrm{c}$ & 74 & $\mathrm{~b}$ & 85 & $a b$ & 288.2 & $a b$ & - Yes \\
\hline $\begin{array}{l}\text { glyphosate + clethodim } \\
+ \text { quizalofop-p-ethyl }\end{array}$ & Triclopyr & 40 & $\mathrm{a}$ & 60 & $\mathrm{a}$ & 82 & $\mathrm{a}$ & 85 & $a b$ & 188.3 & $\mathrm{~b}$ & - Yes \\
\hline $\begin{array}{l}\text { malathion + clethodim } \\
+ \text { quizalofop-p-ethyl }\end{array}$ & Triclopyr & 15 & de & 42 & $\mathrm{~b}$ & 81 & a & 89 & $a b$ & 371.2 & $a b$ & - Yes \\
\hline \multicolumn{2}{|c|}{-----------------------CV\% } & \multicolumn{2}{|c|}{-----13.7----- } & \multicolumn{2}{|c|}{------8.9------ } & \multicolumn{2}{|c|}{-----4.9----- } & -----3 & ------ & ------4 & ------ & \\
\hline
\end{tabular}

${ }^{1}$ Means followed by the same letter in the columns are not significantly different. ${ }^{2}$ Significant at the $1 \%$ probability level by the Tukey test.

the addition of both glyphosate and malathion showed levels of control similar to the sole application of clethodim + quizalofop-p-ethyl (Table 3 ). The association of these graminicides leads to better control when compared to their sole application (BARROSO et al., 2010). For 2,4-D and triclopyr, the herbicide glyphosate presented greater control in the initial evaluations in comparison to malathion. 
In the final evaluations, glyphosate and malathion showed the same mitigation capacity of the 2,4-D and triclopyr antagonism (Table 3).

Overall, the herbicides clethodim and clethodim + quizalofop-p-ethyl were more efficient in the control of ryegrass than quizalofop-p-ethyl. The antagonistic effect of 2,4-D was superior to triclopyr in some cases. Moreover, glyphosate presented a greater capacity to mitigate the antagonistic effect than malathion. The association of glyphosate with graminicide improves control over Digitaria insularis (BARROSO et al., 2014; CASSOL et al., 2019). The formulated mixture of clethodim + quizalofop-p-ethyl suffered less interference from synthetic auxins in ryegrass control than clethodim and quizalofop-p-ethyl. The fact that the insecticide malathion mitigates the antagonistic effect of the mixture, suggesting that the possible mechanism of antagonism is the expression of $\mathrm{P} 450$ monooxygenase enzymes triggered by the auxin herbicides. However, this insecticide can lead to greater absorption and translocation of the herbicides, improving their efficiency (MINTON et al., 2008).

Note that the association of ACCase enzyme inhibiting herbicides with 2,4-D and triclopyr causes a small reduction over ryegrass control. A separate application can result in higher operation cost, more weather dependence for applications and, in crops with tolerance, can generate greater trampling. In addition to these factors, the economic aspect must be considered (TREZZI et al., 2007). Sequential applications of herbicides would improve performance, as in Digitaria insularis and Conyza bonariensis, where excellent controls are obtained (LAMEGO et al., 2013; CORREIA et al., 2015). The adoption of weed control planning allows the association of herbicides to be conducted without hindrance, providing a broad spectrum mixture controlling both narrow- and wide-leaf weeds, which already have resistance to glyphosate; conversely, when it is conducted in a single way, the association should be assessed.

\section{CONCLUSION}

The formulated mixture of clethodim + quizalofop-p-ethyl obtained better performance over ryegrass control when associated with auxin herbicidesthan other graminicides. The increase of the dose of the ACCase enzyme inhibiting herbicide is an alternative for compensating the antagonistic effect. As for the herbicide clethodim, the increase of around $20 \%$ compensates for the association with $2,4-\mathrm{D}$ and triclopyr. Other ways to mitigate the antagonistic effect of auxin herbicides is the application of glyphosate or malathion. One of the possible causes of the antagonism caused by 2,4-D and triclopyr may be related to the expression of genes encoding P450 monooxygenases enzymes and to the absorption and translocation problems.

\section{ACKNOWLEDGEMENTS}

The authors are grateful to the Conselho Nacional de Desenvolvimento Científico e Tecnológico ( $\mathrm{CNPq})$ as well as to the Research Support Foundation of the state of Rio Grande do Sul (FAPERGS) and the Instituto Federal do Rio Grande do Sul (IFRS) for supporting the research and for the scholarships awarded. And was financed in part by the Coordenação de Aperfeiçoamento de Pessoal de Nível Superior (CAPES), Brasil.

\section{DECLARATION OF CONFLICT OF INTERESTS}

The authors declare no conflict of interest. The founding sponsors had no role in the design of the study; in the collection, analyses, or interpretation of data; in the writing of the manuscript, and in the decision to publish the results.

\section{AUTHORS' CONTRIBUTIONS}

All authors have contributed equally to the conception and writing of the manuscript. All authors have critically reviewed the manuscript and approved the final version.

\section{REFERENCES}

ABIT, M. J. M. et al. Efficacy of postemergence herbicides tankmixes in aryloxyphenoxypropionate-resistant grain sorghum. Crop Protection, v.30, p.1623-1628, 2011. Available from: $<$ https://doi.org/10.1016/j.cropro.2011.08.011>. Accessed: Jun. 10, 2019.

AHMAD-HAMDANI, M. S. et al. ACCase-inhibiting herbicideresistant Avena spp. populations from the Western Australian grain belt. Weed Technology, v.26, p.130-136, 2012. Available from: <https://doi.org/10.1614/WT-D-11-00089.1>. Accessed: Jul. 02,2019 .

BARROSO, A. A. M. et al. Accase and glyphosate diferent formulations herbicides association interactions on sourgrass control. Planta Daninha, v.32, p.619-627, 2014. Available from: $\quad<$ http://dx.doi.org/10.1590/S0100-83582014000300018>. Accessed: May, 20, 2019.

BARROSO, A. L. L. et al. Efficacy of ACCase-inhibiting herbicides in controlling grass weeds in soybean crops. Planta Daninha, v.28, p.149-157, 2010. Available from: < http://dx.doi.org/10.1590/ S0100-83582010000100018>. Accessed: May, 20, 2019.

CASSOL, M. et al. Efficiency of isolated and associated herbicides to control glyphosate-resistant sourgrass. Planta Daninha, v.37, 2019. Available from: <https://doi.org/10.1590/s010083582019370100060>. Accessed: Jul. 29, 2020. 
COLBY, S. R. Calculating synergistic and antagonistic responses of herbicide combinations. Weeds, p.20-22, 1967. Available from: $<$ https://www.jstor.org/stable/4041058>. Accessed: Apr. 24, 2019. doi: $10.2307 / 4041058$.

CORREIA, N. M. et al. Chemical control of different Digitaria insularis populations and management of a glyphosate-resistant population. Planta daninha, v.33, p.93-101, 2015. Available from: $\quad<$ http://dx.doi.org/10.1590/S0100-83582015000100011>. Accessed: Jun. 20, 2019.

COX, M. C.; ASKEW, S. D. Metamifop rates, application timings, and broadleaf herbicide admixtures affect smooth crabgrass control in turf. Weed technology, v.28, p.617-625, 2014. Available from: <https:// doi.org/10.1614/WT-D-14-00011.1>. Accessed: Jul. 10, 2019.

DE OLIVEIRA JR, Rubem Silvério; CONSTANTIN, Jamil; INOUE, Miriam Hiroko. Biologia e manejo de plantas daninhas. Curitiba: Omnipax, 2011, 167-168p.

DIESEL, F. et al. Interaction between saflufenacil and other oxidative stress promoting herbicides to control wild poinsettia. Planta Daninha, v.36, 2018. Available from: $<$ http://dx.doi.org/10.1590/s0100-83582018360100093>. Accessed: Jul. 10, 2019.

DOROH, M. C et al. Evaluation of new aryloxyphenoxypropionate herbicides for control of bermudagrass in zoysiagrass. Weed technology, v.25, p.97-102, 2011. Available from: <https://doi. org/10.1614/WT-D-10-00104.1>. Accessed: Jun. 14, 2019.

GAZOLA, T. et al. Effects of 2,4-D herbicide on species of the Digitaria genus. Planta Daninha, v.37, 2019. Available from: $<$ https://doi.org/10.1590/s0100-83582019370100131>. Accessed: Jul. 29, 2020.

GUERRA, N. et al. Aminocyclopyrachlor e indaziflam: Seletividade, controle e comportamento no ambiente. Revista Brasileira de Herbicidas, v.12, p.285-295, 2013. Available from: $<$ https://doi.org/10.7824/rbh.v12i3.246>. Accessed: May, 25, 2019.

HAN, H. et al. Enhanced herbicide metabolism induced by 2,4-D in herbicide susceptible Lolium rigidum provides protection against diclofop-methyl. Pest management science, v.69, p.9961000, 2013. Available from: <https://doi.org/10.1002/ps.3552>. Accessed: Jun. 14, 2019.

HEAP, I. The international herbicide-resistant weed database Available from: <www.weedscience.org > . Accessed: Mar. 07, 2020.

HIROSE, S. et al. Tissue-specific expression of rice CYP72A21 induced by auxins and herbicides. Plant Biotechnol Rep, v.1, p.27-36, 2007. Available from: <https://doi.org/10.1007/s11816006-0003-2>. Accessed: Jun. 18, 2019.

IWAKAMI, S. et al. CYP81A P450s are involved in concomitant cross-resistance to acetolactate synthase and acetyl-CoA carboxylase herbicides in Echinochloa phyllopogon. New Phytol, v.221, p.2112-2122, 2018. Available from: <https://doi. org/10.1111/nph.15552>. Accessed: Jun. 18, 2019.

KASPARY, T. E. et al. Photosynthetic pigments in Italian ryegrass susceptible and resistant to the herbicide glyphosate. Ciência Rural, v.44, p.1901-1907, 2014. Available from: <http://dx.doi. org/10.1590/0103-8478cr20131177>. Accessed: Aug. 10, 2019.
KREUZ, K. et al. Metabolism of the aryloxyphenoxypropanoate herbicide, CGA-184927, in wheat, barley and maize - differentialeffects of the safener, CGA-185072. Z Naturforsch, v.46, p.901905, 1991. Available from: <https://doi.org/10.1515/znc-1991-91030>. Accessed: Jun. 18, 2019.

LAMEGO, F. P et al. Manejo de Conyza bonariensis resistente ao glyphosate: coberturas de inverno e herbicidas em pré-semeadura da soja. Planta Daninha, v.31, p.433-442, 2013. Available from: $\quad<$ http://dx.doi.org/10.1590/S0100-83582013000200022>. Accessed: Jul. 02, 2019

LANCASTER, Z. D. et al. Evaluation of quizalofop tank-mixtures for quizalofop-resistant rice. Crop Protection, v.116, p.7-14, 2019. Available from: <https://doi.org/10.1016/j.cropro.2018.10.004>. Accessed: Jun. 06, 2019.

LEWIS, D. F. et al. Efficacy and safening of aryloxyphenoxypropionate herbicides when tank-mixed with triclopyr for bermudagrass control in zoysiagrass turf. Weed Technology, v.24, p.489-494, 2010. Available from: $<$ https://doi. org/10.1614/WT-D-10-00029.1>. Accessed: Jun. 10, 2019.

MATZENBACHER, F. de O. et al. Antagonism is the predominant effect of herbicide mixtures used for imidazolinone-resistant barnyardgrass (Echinochloa crus-galli) control. Planta Daninha, v.33, p.587-597, 2015. Available from: <http://dx.doi.org/10.1590/ S0100-83582015000300021>. Accessed: May, 25, 2019.

MINTON, B. et al. The influence of malathion on trifloxysulfuron absorption and translocation in cotton. Journal of Cotton Science, v.12, p.48-52, 2008. Available from: <https://www.researchgate. net/publication/242189805 The Influence of Malathion on Trifloxysulfuron_Absorption_and_Translocation_in_Cotton $>$. Accessed: Jul. 27, 2020.

PEREIRA, G. R. et al. Sourgrass response to mixtures of haloxyfop and glyphosate with synthetic auxinic herbicides. Revista Brasileira de Herbicidas, v.17, p.606-1-7, 2018. Available from: <https://doi.org/10.7824/rbh.v17i2.606>. Accessed: Jun. 18, 2019.

ROMANO, M. L. et al. The Effect of monooxygenase and glutathione-S-transferase inhibitors on the metabolism of diclofopmethyl and fenoxaprop-ethyl in barley and wheat. Pestic Biochem Physiol, v.46, p.181-189, 1993. Available from: <https://doi org/10.1006/pest.1993.1049>. Accessed: Jun. 18, 2019.

SCHERDER, E. F. et al. Antagonism of cyhalofop grass activity by halosulfuron, Triclopyr, and Propanil.Weed Technology, v.19, p. 934-941, 2005. Available from: <https://doi.org/10.1614/WT-03177R2.1>. Accessed: May, 24, 2019.

SIMINSZKY, B. Plant cytochrome P450-mediated herbicide metabolism. Phytochemistry Reviews, v.5, p.445-458, 2006. Available from: <https://doi.org/10.1007/s11101-006-9011-7>. Accessed: Jun. 21, 2019.

STRECK, E. V. et al. Solos do Rio Grande do Sul. 3. ed., rev. e ampl. Porto Alegre: Emater/RS-Ascar, 2018, 112-115p.

TREZZI, M. M. et al. Antagonistic action of clodinafop-propargyl associated with Metsulfuron-methyl and 2,4-D in the control of italian ryegrass (Lolium multiflorum). Planta Daninha, v.25, p.839-847, 2007. Available from: <http://dx.doi.org/10.1590/ S0100-83582007000400021>. Accessed: May, 28, 2019. 
TREZZI, M. M. et al. Interactions of saflufenacil with other herbicides promoters of oxidative stress to control joyweed. Planta Daninha, v.34, p.319-326, 2016. Available from: $<\mathrm{http}$ ://dx.doi.org/10.1590/S0100-83582016340200013>. Accessed: Aug. 10, 2019.

UNDERWOOD, M. G. et al. The addition of dicamba to POST applications of quizalofop-p-ethyl or clethodim antagonizes volunteer glyphosate-resistant corn control in dicamba-resistant soybean. Weed technology, v.30, p.639-647, 2016. Available from: <https://doi.org/10.1614/WT-D-16-00016.1>. Accessed: Aug. 10, 2019

VIDAL, R. A.; MERROTO JR., A. Herbicidologia. Porto Alegre: Evangraf, 2001. 152p.

VILA-AIUB, M.M. et al. Resistance cost of a cytochrome P450 herbicide metabolism mechanism but not an ACCase target site mutation in a multiple resistant Lolium rigidum population. New Phytol, v.167, p.787-796, 2005. Available from: <https:// doi.org/10.1111/j.1469-8137.2005.01465.x>. Accessed: Jun. 19, 2019.
WEBSTER, E. P. et al. Quizalofop-p-ethyl mixed with synthetic auxin and ACCase-inhibiting herbicides for weed management in rice production. International Journal of Agronomy, v.2019, 2019. Available from: <https://doi.org/10.1155/2019/6137318>. Accessed: Aug. 06, 2019.

WHITE, G. M. et al. Differences in the molecular basis of resistance to the cyclohexanedione herbicide sethoxydim in Lolium multiflorum. Weed Research, v.45, n.6, p.440-448, 2005. Available from: $<$ https://doi.org/10.1111/j.1365-3180.2005.00478. x>. Accessed: Jul. 28, 2020.

YASOUR, H. et al. Mechanism of resistance to penoxsulam in late watergrass (Echinochloa phyllopogon (Stapf) Koss.). Journal of Agricultural and Food Chemistry, v.57, p.3653-3660, 2009. Available from: <https://doi.org/10.1021/jf8039999>. Accessed: Jun. 15, 2019.

YU, Q.; POWLES, S. Metabolism-based herbicide resistance and cross-resistance in crop weeds: a threat to herbicide sustainability and global crop production. Plant Physiology, v.166, n.3, p.1106-1118, 2014. Available from: <https://dx.doi. org/10.1104\%2Fpp.114.242750>. Accessed: May, 08, 2020. 